\title{
PENINGKATAN HASIL BELAJAR SISWA KELAS VI SDN 02 TOYOMARTO MATERI LUAS BANGUN DATAR GABUNGAN DENGAN MODEL PEMBELAJARAN JIGSAW
}

\author{
Hariyanto \\ Sekolah Dasar Negeri 02 Toyomarto Singosari, Malang \\ E-mail: h428729@gmail.com
}

\begin{abstract}
The purpose of this research is to know the improvement of the result of the study of the widespread joint building material in the second grade students in SD Negeri 02 Toyomarto Singosari with Jigsaw learning model. The research method using Classroom Action Research with 2 cycles consisting of 4 phases, namely planning, action, observation and reflection. Data collection method used in this research is observation and post test. Data analysis used is descriptive quantitative data analysis obtained from observation result of learning and post test result at every meeting. The result of the analysis shows that learning with Jigsaw learning model can improve the result of the study of the joint wake up area in the students of class VI SDN 02 Toyomarto academic year 2017/2018. The average value of cognitive learning outcomes I (60.82), then the average cognitive learning outcome II (78.9) showed an increase compared to cognitive learning outcomes I. In addition, Jigsaw learning model also improves student activeness. This is indicated by the percentage of active students more on the learning cycle II $(31.11 \%)$ compared to cycle I $(13, \%)$.
\end{abstract}

Key Words: jigsaw learning model; learning outcome; two-dimentional figure combined area

\begin{abstract}
ABSTRAK
Tujuan penelitian ini adalah untuk mengetahui peningkatan hasil belajar materi luas bangun datar gabungan pada siswa kelas VI di SD Negeri 02 Toyomarto Singosari dengan model pembelajaran Jigsaw. Metode penelitian menggunakan Penelitian Tindakan Kelas dengan 2 siklus yang terdiri dari 4 fase, yaitu perencanaan, tindakan, observasi dan refleksi. Metode pengumpulan data yang digunakan dalam penelitian ini adalah observasi dan post test. Analisa data yang digunakan adalah analisa data deskriptif kuantitatif yang diperoleh dari hasil observasi saat pembelajaran dan hasil post test pada setiap pertemuan. Hasil analisis menunjukkan bahwa pembelajaran dengan model pembelajaran Jigsaw dapat meningkatkan hasil belajar luas bangun datar gabungan pada siswa kelas VI SDN 02 Toyomarto tahun ajaran 2017/2018. Nilai rata-rata hasil belajar kognitif I $(60,82)$, kemudian rata-rata hasil belajar kognitif II $(78,9)$ menunjukkan adanya peningkatan dibandingkan hasil belajar kognitif I. Selain itu, model pembelajaran Jigsaw juga meningkatkan keaktifan siswa. Hal ini ditunjukkan oleh persentase siswa aktif lebih banyak pada pembelajaran siklus II $(31,11 \%)$ dibandingkan siklus I $(13, \%)$.
\end{abstract}

Kata Kunci : model pembelajaran jigsaw; hasil belajar; luas bangun datar gabungan

\section{PENDAHULUAN}

Pelajaran matematika adalah pelajaran yang selalu dianggap sulit oleh siswa. Saat ini harus disadari bahwa peranan matematika semakin penting seiring dengan perkembangan ilmu pengetahuan dan teknologi (IPTEK). Senada dengan pendapat Hudoyo (1988 : 74) menyatakan 
bahwa matematika bukanlah ilmu yang hanya untuk dirinya sendiri tetapi ilmu yang bermanfaat untuk sebagian besar ilmu lainnya, pernyataan ini menunjukkan bahwa penguasaan materi matematika menjadi keharusan yang tidak bisa ditawar, terutama dalam penataan nalar dan pengambilan keputusan dalam era persaingan yang semakin kompetitif. Selain itu, matematika merupakan salah satu mata pelajaran yang diujikan secara nasional.

Berbagai usaha perbaikan dan peningkatan mutu pembelajaran matematika telah dilakukan oleh pemerintah namun hasil yang dicapai belum sesuai dengan harapan. Hal ini tampak pada masih banyaknya siswa yang kurang berhasil dalam menempuh US pada mata pelajaran matematika. Hal tersebut bukan semata-mata karena siswa yang tidak mampu mengerjakan tetapi bisa juga disebabkan oleh strategi, metode yang diterapkan oleh guru kurang tepat. Oleh sebab itu, diperlukan suatu Penelitian Tindakan Kelas.

Soedjadi juga mengatakan bahwa kurikulum matematika sekolah di Indonesia dalam pembelajaran selama ini masih terbiasa dengan urutan sajian pembelajaran sebagai berikut : (1) diajarkan definisi atau teori/theorem; (2) diberikan contoh-contoh; dan (3) diberikan latihan soal. Menurutnya kebiasaan seperti ini menyebabkan guru mendominasi kegiatan belajar mengajar dan siswa hanya menjadi pendengar dan pencatat yang baik (dalam Fadilla : 2002).

Fakta di SD Negeri 02 Toyomarto Singosari utamanya kelas VI dalam belajar atematika pada pokok bahasan luas bangun datar gabungan masih banyak anak yang mendapat kesulitan dalam memahami materi tersebut, sehingga peneliti termotivasi untuk menggunakan model pembelajaran kooperatif Jigsaw. Proses pembelajaran merupakan proses interaksi antara anak didik (siswa) dan guru sebagai pengajar. Proses pembelajaran dilaksanakan dengan menggunakan pedagogi yang mencakup strategi maupun metode mengajar. Keberhasilan belajar anak didik yang dicapai dapat diukur melalui penilaian hasil belajar yaitu ulangan harian dan tugas.

Kondisi tersebut dapat disebabkan oleh guru yang menggunakan metode ceramah konvensional sehingga siswa hanya mendengarkan, mencatat dengan teliti dan mencoba menyelesaikan soal seperti yang dicontohkan oleh guru. Keadaan tersebut menjadikan siswa pasif dalam pembelajaran sistem pencernaan pada manusia. Pada proses pembelajaran luas bangun datar gabungan, siswa seharusnya berperan aktif sehingga dapat menggunakan kemampuannya untuk mengembangkan kreativitas serta lebih dapat memahami pelajaran dan terampil dalam menyelesaikan permasalahan tersebut. Sebab, kegiatan pembelajaran tidak lain ialah pelaksanaan proses menterjemahkan dan mentransformasikan nilai nilai yang terdapat dalam kurikulum kepada para siswa melalui interaksi belajar mengajar (Nana Sudjana, 1995 : 13). Oleh sebab itu, guru hendaknya mampu memilih dan menerapkan model pembelajaran yang mampu merangsang siswa lebih aktif dalam belajar serta meningkatkan kemampuan siswa dalam memahami luas bangun datar gabungan.

Model pembelajaran kooperatif Jigsaw merupakan pendekatan pembelajaran yang berfokus pada penggunaan kelompok kecil siswa untuk bekerja sama dalam memaksimalkan kondisi belajar untuk mencapai tujuan belajar. Siswa dapat bekerjasama dalam memaksimalkan kondisi belajar untuk mencapai tujuan belajar (Nurhadi dan Senduk, 2003 ; 20). Oleh karena itu, pendekatan pembelajaran Jigsaw dapat mengatasi kelemahan siswa pada pemahaman konsep matematika. Model pembelajaran Jigsaw dapat dilakukan melalui pembagian siswa menjadi beberapa tim yang anggotanya terdiri dari 5 atau 6 siswa dengan karakteristik yang heterogen (Nurhadi, 2004 :112). Kelebihan dari pembelajaran kooperatif Jigsaw yaitu (1) meningkatkan kemampuan siswa; (2) meningkatkan rasa percaya diri; (3) menumbuhkan keinginan untuk menggunakan pengetahuan dan keahlian; (4) memperbaiki hubungan antar kelompok. Penggunaan model pembelajaran kooperatif Jigsaw diharapkan mampu meningkatkan kegiatan-kegiatan pembelajaran yang mendorong siswa belajar aktif baik secara fisik, sosial, maupun psikis dalam memahami konsep luas bangun datar gabungan. 
Masalah tersebut dapat diatasi dengan melaksanakan Penelitian Tindakan Kelas (PTK). Penelitian Tindakan Kelas (PTK) merupakan suatu penelitian yang akar permasalahannya muncul di kelas dan disarankan pemecahan masalahnya langsung oleh guru yang bersangkutan. Pada PTK, peneliti atau guru dapat melihat sendiri praktik pembelajaran. Dapat juga dilaksanakan bersama guru lain, peneliti melakukan penelitian terhadap siswa dilihat dari aspek interaksinya dalam proses pembelajaran. Melalui PTK, guru secara reflektif dapat menganalisis, mensintesis, terhadap apa yang telah dilakukan di kelas sehingga guru dapat memperbaiki praktik-praktik pembelajaran sehingga menjadi lebih efektif (Supardi, 2006).

Berdasarkan uraian tersebut, maka diperlukan Penelitian Tindakan Kelas (PTK) terhadap siswa kelas VI SD Negeri 02 Toyomarto pada pokok bahasan sistem luar bangun datar gabungan dengan menggunakan model pembelajaran Jigsaw. Penggunaan model pembelajaran kooperatif Jigsaw, diharapkan dapat membantu siswa kelas VI untuk memahami konsep materi tersebut. Selain itu, juga dapat membantu siswa untuk lebih aktif dalam pembelajaran matematika khususnya pokok bahasan luas bangun datar gabungan sehingga pembelajaran matematika menjadi lebih bermakna.

\section{Pemahaman Konsep dalam Matematika}

Pemahaman dalam penelitian ini adalah kesanggupan untuk mengenal fakta, konsep, prinsip dan skill. Pemahaman diletakkan dalam hubungan satu dengan yang lain secara benar dan menggunakannya secara tepat pada situasi pemahaman yang meliputi penerimaan dan komunikasi secara akurat sebagai hasil komunikasi dalam pembagian yang berbeda dan mengorganisasi secara singkat tanpa mengubah pengertian. Menurut Syaiful Sagala (2006 : 71) konsep merupakan buah penelitian seseorang atau sekelompok orang yang dinyatakan dalam definisi sehingga menghasilkan produk pengetahuan yang meliputi prinsip, hukum dan teori. Konsep merupakan bagian dasar untuk membangun pengetahuan yang mantap karena konsep merupakan bagian dasar ilmu pengetahuan.

Konsep dalam matematika adalah abstrak yang memungkinkan kita untuk mengelompokkan atau mengklasifikasikan obyek/kejadian. Konsep tingkat tinggi dapat berupa hubungan antara konsep-konsep dasar. Konsep dapat dipelajari melalui definisi atau pengamatan langsung atau dapat dipelajari dengan cara melihat, mendengar, mendiskusikan dan memberikan tentang bermacam-macam contoh. Anak-anak masih berada dalam tahap operasi konkrit belajar konsep biasanya belum mampu melihat dan memegang benda yang dinyatakan oleh konsep itu. Sedangkan proses operasional formal dapat mempelajari konsep melalui diskusi dan memperhatikan sungguh-sungguh. Seseorang telah memahami jika orang tersebut telah mampu memisahkan contoh konsep dan bukan konsep.

\section{Luas Bangun Datar Gabungan}

Menurut Herman Hudoto (1988 : 3) matematika adalah ilmu mengenai struktur yang akan mencakup tentang hubungan, pola maupun bentuk. Matematika berkenaan dengan ideide/gagasan-gagasan, struktur dan hubungan dengan konsep-konsep abstrak. Matematika timbul karena pikiran-pikiran manusia yang berhubungan dengan ide, proses dan penalaran. Matematika terdiri dari 4 wawasan yang luas yaitu aritmatika, aljabar, geometri dan analisa (analisis). Matematika tidak tergantung bidang lain dan harus menggunakan simbol dan istilah yang cermat yang telah disepakati bersama.

Matematika tersusun secara hirarkis yang berkaitan erat. Konsep-konsep matematika pada tingkat yang lebih tinggi dapat dipahami setelah memahami konsep sebelumnya dengan baik. Hal ini berarti belajar matematika harus bertahap dan berurutan secara sistematis serta harus di dasarkan kepada pengalaman belajar terdahulu. Seseorang akan lebih mudah mempelajari suatu materi yang baru bila didasarkan kepada pengetahuan yang telah diketahui dan dipahami. Tujuan belajar matematika adalah untuk mencapai sesuatu setelah proses belajar 
mengajar matematika berlangsung dengan baik dalam jangka pendek maupun jangka panjang. Tujuan belajar matematika jangka pendek yaitu dikuasainya sejumlah materi yang telah dipelajarinya, sedangkan tujuan belajar Matematika jangka panjang adalah berkenaan dengan penggunaan matematika dalam kehidupan sehari-hari.

Luas bangun datar adalah salah satu pokok bahasan yang terdapat pada pelajaran matematika kelas VI semester ganjil. Pokok bahasan luas bangun datar erat kaitannya dengan materi belajar matematika yang telah didapat siswa di kelas IV. Akan tetapi di SD Negeri 02 Toyomarto, siswa merasa kesulitan di dalam menyelesaikan soal-soal hitung luas bangun datar gabungan sehingga peneliti mencoba melakukan Penelitian Tindakan Kelas dengan merubah proses pembelajarannya menggunakan model pembelajaran kooperatif Jigsaw.

\section{Model Pembelajaran Kooperatif Jigsaw}

Model pembelajaran kooperatif Jigsaw adalah salah satu model kooperatif yang paling fleksibel (Slavin, 2005:246). Pembelajaran kooperatif tipe Jigsaw adalah suatu tipe pembelajaran kooperatif yang terdiri dari beberapa anggota dalam satu kelompok yang bertanggung jawab atas penguasaan bagian materi belajar dan mampu mengajarkan materi tersebut kepada anggota lain dalam kelompoknya (Sudrajat, 2008:1). Model pembelajaran Jigsaw merupakan strategi yang menarik untuk digunakan jika materi yang akan dipelajari dapat dibagi menjadi beberapa bagian dan materi tersebut tidak mengharuskan urutan penyampaian. Kelebihan strategi ini adalah dapat melibatkan seluruh peserta didik dalam belajar dan sekaligus mengajarkan kepada orang lain (Zaini, 2008:56). Berikut langkah-langkah dalam model pembelajaran kooperatif Jigsaw menurut Rusman (2008).

Tabel 2.1 Langkah-langkah Model Pembelajaran Kooperatif Jigsaw

\begin{tabular}{|l|l|}
\hline \multicolumn{1}{|c|}{ Tahapan } & \multicolumn{1}{c|}{ Kegiatan yang Dilakukan Siswa } \\
\hline $\begin{array}{l}\text { Membaca untuk menggali } \\
\text { informasi }\end{array}$ & $\begin{array}{l}\text { Siswa memperoleh topik-topik permasalahan untuk } \\
\text { dibaca sehingga mendapatkan informasi dari } \\
\text { permasalahan tersebut }\end{array}$ \\
\hline Diskusi kelompok ahli & $\begin{array}{l}\text { Siswa yang telah mendapatkan topik permasalahan } \\
\text { yang sama bertemu dalam satu kelompok atau kita } \\
\text { sebut dengan kelompok ahli untuk membicaran topik } \\
\text { permasalahan tersebut. }\end{array}$ \\
\hline Laporan kelompok & $\begin{array}{l}\text { Kelompok ahli kembali ke kelompok asal dan } \\
\text { menjelaskan dari hasil yang didapat dari diskusi tim } \\
\text { ahli. }\end{array}$ \\
\hline Kuis & $\begin{array}{l}\text { Tes yang dilakukan mencakup semua topic } \\
\text { permasalahan yang dibicarakan tadi }\end{array}$ \\
\hline Perhitungan skor & $\begin{array}{l}\text { Perhitungan skor kelompok untuk menentukan } \\
\text { penghargaan kelompok }\end{array}$ \\
\hline
\end{tabular}

Menurut Sudrajat (2008), ada beberapa faktor keberhasilan dalam pelaksanaan model pembelajaran Jigsaw, yaitu ketergantungan satu sama lain, tanggung jawab setiap anggota kelompok, interaksi antar individu, kemampuan bersosialisasi, evaluasi kerja kelompok. Dengan mempertimbangkan faktor-faktor tersebut maka proses pembelajaran model Jigsaw dapat berjalan dengan baik sehingga dapat membantu siswa dalam memahami konsep-konsep matematika khususnya konsep luas bangun datar gabungan.

Secara sederhana kerangka pemikiran dari penelitian ini dapat digambarkan sebagai berikut: 


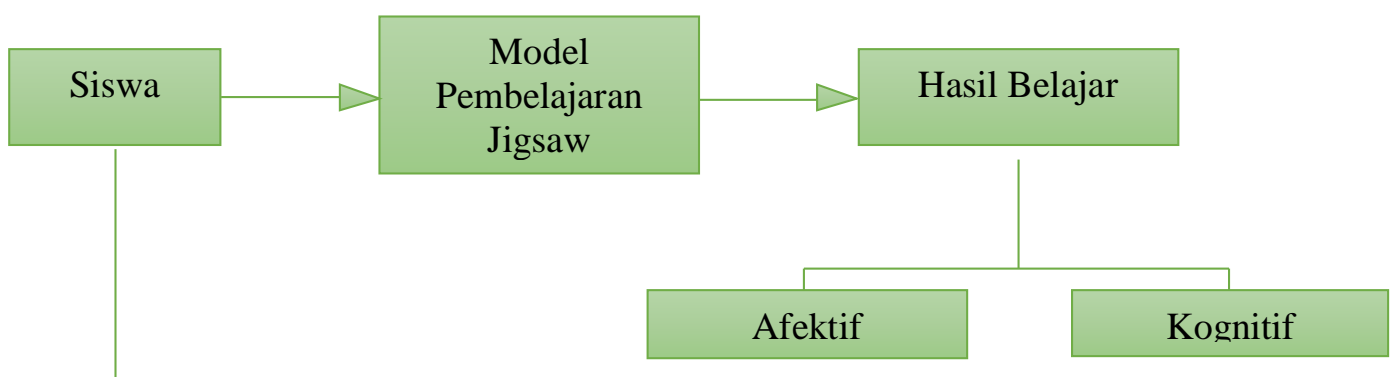

a. Siswa kurang aktif dalam belajar

b. Hasil belaiar siswa rendah

\section{Gambar 1. Diagram Kerangka Berpikir Penelitian}

\section{METODE PENELITIAN}

Penelitian dilakukan di SD Negeri 02 Toyomarto Singosari. Subyek penelitian adalah siswa-siswi kelas VI SD Negeri 02 Toyomarto yang berjumlah 35 siswa dengan menggunakan metode pengambilan sampel purposive yaitu tempat penelitian ditentukan dengan sengaja untuk mencapai tujuan tertentu (Arikunto, 1998 : 192). Penelitian ini dilaksanakan mulai tanggal 20 Agustus 2017 s.d 30 September 2017. Jenis penelitian ini adalah Penelitian Tindakan Kelas (PTK), menurut Hobri (2007 : 1) Penelitian Tindakan Kelas adalah :

a. Penelitian tindakan yang dilakukan di kelas

b. Penelitian yang menyangkut masalah-masalah di kelas

c. Penelitian tindakan yang menyangkut masalah-masalah pendidik dan pembelajar

Prosedur penelitian ini menggunakan tindakan berbentuk spiral dari siklus yang satu ke siklus berikutnya (menurut Kenis dan Tuggart 1988 dalam Hobri). Kegiatan penelitian ini dilakukan sebanyak 2 siklus masing-masing siklus terdiri dari 4 tahap yaitu perencanaan, tindakan, observasi dan refleksi. Langkah-langkah yang dilakukan pada masing-masing siklus seperti terlihat pada tabel berikut ini :

Tabel 1. Langkah-Langkah Pelaksanaan Setiap Siklus

\begin{tabular}{|c|c|c|}
\hline Siklus & Kegiatan & Pelaksanaan \\
\hline \multirow[t]{4}{*}{ Siklus I } & Perencanaan & $\begin{array}{l}\text { 1. Refleksi awal } \\
\text { 2. Membuat perangkat dan instrumen tentang luas bangun datar gabungan }\end{array}$ \\
\hline & Tindakan & $\begin{array}{l}\text { 1. Kegiatan awal } \\
\text { a. Menyampaikan tujuan dan memotivasi siswa } \\
\text { b. Mengorganisasikan siswa dalam kelompok } \\
\text { c. Menentukan topik bahasan } \\
\text { 2. Kegiatan inti } \\
\text { a. Guru memberi tugas berupa latihan soal } \\
\text { b. Siswa mempelajari tugas } \\
\text { c. Diskusi kelompok ahli } \\
\text { d. Menjelaskan kepada kelompok awal } \\
\text { e. Mengerjakan post test } \\
\text { 3. Kegiatan akhir } \\
\text { a. Membahas port test } \\
\text { b. Guru memberikan penghargaan pada kelompok dan individu }\end{array}$ \\
\hline & Observasi & $\begin{array}{l}\text { 1. Mengamati aktivitas siswa } \\
\text { 2. Membuat catatan lapangan }\end{array}$ \\
\hline & Refleksi & $\begin{array}{l}\text { 1. Menganalisis, menyimpulkan dan mengiterpretasi data } \\
\text { 2. Memberikan pertimbangan pada siklus II }\end{array}$ \\
\hline
\end{tabular}




\begin{tabular}{|c|c|c|}
\hline \multirow[t]{4}{*}{ Siklis II } & Perencanaan & $\begin{array}{l}\text { 1. Memberikan info pada siswa tentang hasil siklus I } \\
\text { 2. Menyusun perangkat dan instrumen yang sudah diperbaiki dari siklus I }\end{array}$ \\
\hline & Tindakan & $\begin{array}{l}\text { 1. Kegiatan awal } \\
\text { a. Menyampaikan tujuan dan memotivasi siswa } \\
\text { b. Mengorganisasikan siswa dalam kelompok } \\
\text { c. Menentukan topik bahasan } \\
\text { 2. Kegiatan inti } \\
\text { a. Guru membagi tugas pada siswa } \\
\text { b. Siswa mempelajari tugas dengan bimbingan guru } \\
\text { c. Diskusi kelompok ahli dengan bimbingan guru } \\
\text { d. Menjelaskan kepada kelompok asal } \\
\text { e. Mengerjakan post test } \\
\text { 3. Kegiatan akhir } \\
\text { a. Membahas post test } \\
\text { b. Memberi penghargaan pada kelompok dan individu }\end{array}$ \\
\hline & Observasi & $\begin{array}{l}\text { 1. Mengamati aktivitas siswa pada saat pembelajaran } \\
\text { 2. Membuat catatan lapangan }\end{array}$ \\
\hline & Refleksi & $\begin{array}{l}\text { 1. Menganalisa data dan menginterpretasi data } \\
\text { 2. Membuat kesimpulan }\end{array}$ \\
\hline
\end{tabular}

Data yang dikumpulkan berupa data hasil observasi proses pembelajaran dan hasil belajar siswa pada materi luas bangun datar gabungan. Instrumen yang digunakan adalah Rencana Pelakasanaan Pembelajaran dengan Model Jigsaw, lembar observasi saat pembelajaran Jigsaw berlangsung, dan hasil belajar siswa dari soal posttest. Metode pengumpulan data yang akan digunakan dalam penelitian ini adalah observasi dan posttest. Analisa data yang digunakan adalah analisa data deskriptif kuantitatif yang diperoleh dari :

1. Hasil observasi yang memuat catatan tentang kegiatan pembelajaran baik yang berhubungan dengan guru maupun yang berhubungan dengan siswa

2. Hasil posttest pada setiap pertemuan setelah menggunakan model pembelajaran Jigsaw Rumus yang digunakan dalam mengolah data dan menganalisis data antara lain :

a. $\quad$ Rata-rata $($ Mean $=M)$

$$
x=\frac{\text { Total Nilai }}{\text { Jumlah Siswa }}
$$

Rumus tersebut digunakan untuk menghitung perkembangan dan peningkatan proses belajar siswa, jika dibandingkan antara siklus yang satu dengan siklus yang lainnya.

b. Mencari ketuntasan belajar klasikal

$$
\text { Ketuntasan Belajar Klasikal }=\frac{\text { Jumlah siswa tuntas }}{\text { Jumlah seluruh siswa }} \times 100 \%
$$

Untuk menentukan seorang siswa tergolong tuntas atau tidak tuntas sebagai tolak ukur adalah KKM (Kriteria Ketuntasan Minimal) yang telah ditetapkan oleh guru. KKm tersebut sebesar 70 dengan ketuntasan klasikal minimal sebesar $85 \%$.

c. Ktiteria keberhasilan penelitian

Untuk mengukur penelitian ini telah mencapai keberhasilan sesuai dengan tujuan yang diharapkan atau belum, maka sebagai kriterianya atau tolak ukurnya adalah :

- Bila telah mencapai kriteria ketuntasan belajar klasikal yaitu minimal 85\% siswa dalam satu kelas memperoleh nilai sesuai KKM ke atas.

- $\quad$ Bila nilai rata-rata yang diperoleh siswa minimal 70. 


\section{HASIL PENELITIAN DAN PEMBAHASAN}

\section{A. Hasil Penelitian \\ 1. Hasil Penelitian Siklus I \\ a. Perencanaan}

Tahap perencanaan pada siklus I adalah membuat rencana pembelajaran. Adapun materi yang dibahas dalam perangkat pembelajaran tersebut adalah pokok bahasan hitung luas bangun datar gabungan dengan kompetensi dasar mengetahui dan menghitung bangun datar yang ada pada bangun gabungan tersebut. Langkah-langkah penelitian yang disusun dalam rencana pembelajaran didesain sesuai dengan langkah-langkah pada model pembelajaran kooperatif Jigsaw. Kemudian dilanjutkan membuat instrumen penelitian yaitu lembar pengamatan aktivitas dan membuat alat evaluasi untuk mengetahui pemahaman konsep siswa terhadap materi pelajaran setelah pembelajaran berlangsung dengan menggunakan model pembelajaran kooperatif Jigsaw.

\section{b. Implementasi Tindakan}

Guru memulai pelajaran dengan menyampaikan tujuan sesuai dengan indikator menentukan luas bangun datar gabungan dan menentukan serta menghitung luas bangun datar yang ada pada bangun gabungan tersebut dengan mengingatkan siswa pada materi pertemuan sebelumnya dan memotivasi siswa dengan pembelajaran yang akan dilaksanakan hari ini yaitu dengan menggunakan model pembelajaran Jigsaw. Guru menjelaskan langkah-langkah kerjanya dengan menyuruh siswa berkelompok yang masing-masing kelompok beranggotakan 4-5 orang dan kelompok tersebut disebut kelompok asal.

Pada kegiatan inti, guru melaksanakan langkah-langkah berikut:

- Guru memberikan permasalahan berupa latihan soal yaitu tentang menentukan luas bangun datar gabungan, setiap anggota kelompok asal mendapat tugas mengerjakan 1 butir soal.

- Guru meminta siswa agar anggota kelompok yang menerima tugas yang sama membentuk kelompok baru yang selanjutnya disebut kelompok ahli. Masing-masing kelompok ahli berdiskusi untuk mengerjakan tugas tersebut selama 15 menit kemudian guru mengingatkan bahwa setiap siswa harus benar-benar memahami soal yang ditugaskan tersebut, karena nantinya akan menjelaskan apa yang didiskusikan di kelompok ahli kepada temannya di kelompok asal. Pada diskusi itu siswa dapat bertanya, mengemukakan pendapat, interupsi, memberi saran, membuat kesimpulan, dan sebagainya (pada saat siswa di kelompok ahli berdiskusi guru mengamati menggunakan lembar pengamatan). Ada siswa yang aktif, ada siswa yang bercanda, ada yang membaca buku, ada yang menggoda temannya, melihat kejadian tersebut guru mengingatkan kembali bahwa siswa harus diskusi agar semua anggota kelompok mengerti karena nantinya akan menjelaskan di kelompok asal.

- Masing-masing anggota kelompok ahli kembali ke kelompok asalnya untuk menjelaskan penyelesaian soal- soal yang dibahas di kelompok ahli pada kelompok asalnya \pm 20 menit. Kemudian guru memberikan instruksi secara klasikal kepada seluruh siswa untuk membahas atau menjelaskan soal-soal tersebut di depan mulai dari siswa yang mengerjakan soal nomor 1 secara berurutan sampai nomor 5. Saat seorang siswa menjelaskan soal nomor 2 di depan, ada siswa lainnya bertanya karena masih belum jelas tentang penyelesaian soal tersebut. Guru melempar kepada anggota kelompok ahli tadi yang bisa menjelaskan soal nomor 2 sehingga siswa yang bertanya tadi merasa jelas. Peranan guru memberi penguatan tentang penyelesaian soal nomor 1 sampai 5 . (15 menit)

- Kemudian guru memberi posttest yang berkaitan dengan soal yang tadi dibahas di masingmasing kelompok untuk dikerjakan selama 15 menit.

Pada kegiatan penutup, siswa dan guru membahas soal posttest tadi yang diberikan/dikerjakan siswa. Memberikan penghargaan kepada kelompok yang sangat aktif di 
dalam berdiskusi dan kepada siswa yang berhasil menjelaskan soal dengan baik. Berikut ini adalah hasil posttest pada siklus I

Tabel 2. Rekapitulasi Hasil Posttest Pada Siklus I

\begin{tabular}{|c|c|c|c|}
\hline No & Nilai Siswa & Jumlah Siswa & $\%$ Siswa \\
\hline 1. & $\leq 70$ & 20 & $57,14 \%$ \\
\hline 2. & $\geq 70$ & 15 & $42,58 \%$ \\
\hline & Jumlah & 45 & $100 \%$ \\
\hline
\end{tabular}

Keterangan

Nilai terendah : 30

Nilai tertinggi : 90

Nilai rata-rata $: 60,82$

Dari Tabel 2, menunjukkan bahwa siswa yang memperoleh nilai di atas 70 sebanyak 15 siswa $(42,58 \%)$ dan sebanyak 20 siswa $(57,14 \%)$ dalam kategori kurang. Hal ini membutuhkan siklus 2 untuk perbaikan pembelajaran.

\section{c. Observasi}

Hasil pengamatan guru selama proses pembelajaran berlangsung tentang keaktifan siswa dalam kegiatan pembelajaran pada siklus I ada pada tabel berikut ini.

Tabel 3. Keaktifan Siswa pada Siklus I

\begin{tabular}{|c|l|c|}
\hline No. Item & \multicolumn{1}{|c|}{ Indikator } & Jumlah (\%) \\
\hline 1. & Siswa sangat aktif & $13,33 \%$ \\
\hline 2. & Siswa aktif & $24,44 \%$ \\
\hline 3. & Siswa biasa saja & $26,67 \%$ \\
\hline 4. & Siswa pasif & $35,56 \%$ \\
\hline
\end{tabular}

Dari tabel tersebut masih banyak siswa yang pasif selama proses kegiatan pembelajaran berlangsung. Kemungkinan siswa yang pasif karena masih belum paham tentang materi soal yang dimaksud sehingga menurut guru masih perlu penekanan lagi pada siswa untuk lebih bersungguh-sungguh selama mengikuti proses diskusi.

\section{d. Refleksi}

Dengan memperhatikan respon siswa pada hasil pengamatan siswa serta hasil post test diperoleh hal-hal sebagai berikut :

1) Siswa yang sangat aktif atau dominan dalam kelompoknya masih 13,33\%. Hal ini berpengaruh terhadap hasil post test yang masih banyaknya siswa mendapat nilai dibawah KKM yaitu $57,14 \%$.

2) Keaktifan siswa tersebut terjadi karena memang siswa belum memahami materi yang sudah diberikan guru. Oleh sebab itu, perangkat pembelajaran dan instrumen pada siklus II desainnya tetap seperti pada siklus I.

3) Untuk meningkatkan kemampuan siswa dalam memahami konsep luas bangun datar gabungan maka langkah pembelajaran pada siklus II akan sedikit berubah. Perubahan yang dimaksud adalah soal-soal yang diberikan akan berbeda, pada saat siswa berdiskusi di kelompok ahli ataupun di kelompok asal guru akan melakukan pendampingan ke tiap-tiap kelompok untuk memberi penekanan pada tiap-tiap kelompok.

\section{Hasil Penelitian Siklus II}

a. Perencanaan

Seperti halnya pada siklus I, tahap perencanaan pada siklus II adalah memberikan info pada siswa tentang hasil evaluasi di siklus I kemudian guru juga mengulang kembali tentang 
materi pada pertemuan yang lalu juga dengan soal diskusi yang berbeda. Guru memotivasi siswa hendaknya lebih bersungguh-sungguh dalam mengikuti diskusi di kelompok masingmasing. Sedangkan instrumen yang digunakan sama dengan pada siklus I yaitu lembar pengamatan siswa dan post test.

\section{b. Pelaksanaan dan Observasi}

Tahap ini merupakan pelaksanaan kelanjutan dari pelaksanaan tindakan pada siklus I dengan alur yang sama pula dan dengan pembagian waktu yang sama selama proses pembelajaran berlangsung. Perubahan terletak pada soal diskusi yang diberikan kepada siswa dan tindakan guru untuk melakukan pendampingan dan bimbingan di setiap kelompok pada saat diskusi berlangsung. Pada pelaksanaan siklus II, sudah ada peningkatan dalam pemahaman materi untuk mengerjakan soal, kegiatan diskusi tidak lagi didominasi siswa yang pandai. Siswa yang pasif tidak terlihat lagi sehingga kegiatan diskusi pada siklus II dapat berjalan lebih baik dibandingkan dengan kegiatan diskusi pada siklus I. Suasana kelas lebih hidup dan dalam proses pembelajaran siklus II terkesan menyenangkan hal ini terlihat pada tabel observasi berikut ini.

Tabel 4. Keaktifan Siswa pada Siklus II

\begin{tabular}{|c|l|c|}
\hline No. Item & \multicolumn{1}{c|}{ Indikator } & Jumlah (\%) \\
\hline 1. & Siswa sangat aktif & $31,11 \%$ \\
\hline 2. & Siswa aktif & $26,67 \%$ \\
\hline 3. & Siswa biasa saja & $24,44 \%$ \\
\hline 4. & Siswa pasif & $17,78 \%$ \\
\hline
\end{tabular}

Dari tabel tersebut ternyata ada peningkatan yang signifikan pada keaktifan siswa sehingga sangat berpengaruh pada hasil post test siklus II yang rekapitulasinya pada tabel berikut ini.

Tabel 5. Rekapitulasi Hasil Posttest pada Siklus II

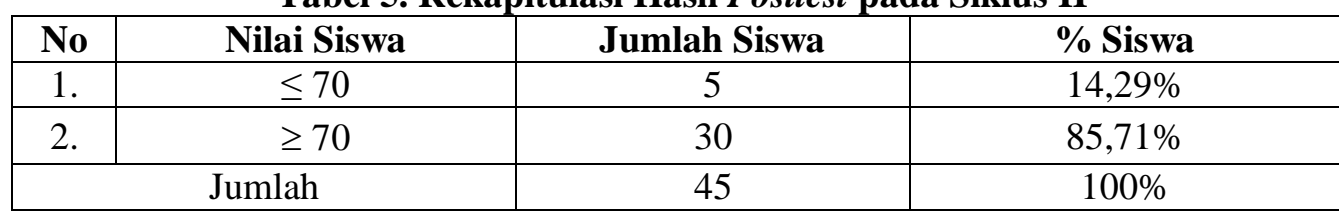

Keterangan

Nilai terendah : 40

Nilai tertinggi : 100

Nilai rata-rata $: 78,90$

Dari tabel 5 menunjukkan bahwa dengan model pembelajaran Jigsaw dapat meningkatkan pemahaman konsep matematika pada pokok bahasan luas bangun datar gabungan. Kemampuan siswa dalam kelompoknya meningkat. Hal ini tampak pada saat mengerjakan soal-soal posttest siswa lebih percaya diri terbukti pada tabel 5, jumlah siswa yang berhasil baik 30 siswa $(85,71 \%)$ dan sebayak 5 siswa $(14,29 \%)$ belum tuntas. Namun hasil observasi aktivitas siswa terjadi peningkatan dari siklus I ke siklus II. Dengan penerapan model pembelajaran kooperatif Jigsaw ternyata mampu meningkatkan kualitas pemahaman siswa.

\section{c. Refleksi} berikut :

Dengan memperhatikan hasil pengamatan kepada siswa diperoleh hal-hal sebagai

1) Prosentase siswa yang sangat aktif pada siklus II $31,11 \%$ lebih meningkat dari prosentase siswa yang sangat aktif pada siklus I 13,33\%

2) Prosentase siswa yang memperoleh di atas KKM adalah $85,71 \%$. Hal ini menunjukkan perubahan langkah pembelajaran yang digunakan oleh guru cukup efektif dalam 
memotivasi siswa untuk lebih memahami konsep sehingga bisa mengerjakan soal-soal yang diberikan.

3) Pengetahuan yang bermakna diperoleh dari proses pengetahuan yang dimiliki siswa diperluas melalui konteks pembelajaran yang kemudian diperluas sedikit demi sedikit

4) Guru membantu siswa membuat hubungan pengetahuan yang dimiliki sebelumnya dengan pengetahuan yang baru dengan begitu siswa memperoleh sesuatu yang berguna bagi dirinya tentang apa yang dipelajarinya

5) Kunci dari semua itu adalah bagian pengetahuan itu mengendap di benak siswa, siswa memahami apa yang sudah dipelajari dan bagaimana menggunakan pemahaman yang ada untuk menyelesaikan soal-soal luas bangun datar gabungan.

\section{B. Pembahasan}

Pada pelaksanaan Penelitian Tindakan Kelas yang dilakukan peneliti menunjukkan bahwa model pembelajaran kooperatif Jigsaw dapat meningkatkan pemahaman konsep siswa dalam pembelajaran matematika. Hal ini terlihat dari hasil penelitian bahwa terdapat perbedaan yang signifikan mulai dari kegiatan yang dilakukan peneliti pada saat observasi kegiatan proses pembelajaran dengan selisih 33,34\% dari siklus I menuju Siklus II berarti siswa sangat menyukai proses pembelajaran dengan model pembelajaran Jigsaw ini. Hasil belajar (prestasi) yang diperoleh siswa menunjukkan hasil yang baik dengan menggunakan model pembelajaran kooperatif Jigsaw. Hal ini terlihat dari hasil penelitian pada tabel rekapitulasi hasil post test pada siklus I dan siklus II terjadi perbedaan yang sangat signifikan. Berarti dengan model pembelajaran kooperatif Jigsaw dapat meningkatkan pemahaman konsep siswa pada pokok bahasan luas bangun datar gabungan. Pada siklus II jumlah siswa yang berhasil baik 30 siswa $(85,71 \%)$ dan sebanyak 5 siswa $(14,29 \%)$ belum tuntas. Dengan penerapan model pembelajaran kooperatif Jigsaw ternyata mampu meningkatkan kualitas pemahaman konsep siswa pada matematika.

Melalui model pembelajaran sebelumnya, yaitu metode konvensional ternyata belum menarik minat siswa sehingga belum mencapai hasil belajar yang optimal. Adanya upaya yang dilakukan oleh peneliti, ternyata hasil belajar siswa kelas VI SDN 02 Toyomarto Singosari dapat meningkat. Upaya yang dilakukan peneliti ternyata membawa dampak positif terhadap prestasi belajar siswa kelas VI SD Negeri 02 Toyomarto Singosari. Hasil penelitian menunjukkan peningkatan yang signifikan yang didapatkan oleh siswa dalam belajar baik secara klasikal maupun individual.

\section{PENUTUP}

Berdasarkan hasil penelitian dan pembahasan yang telah dikemukakan dapat ditarik kesimpilan sebagai berikut :

1. Kualitas pemahaman konsep siswa pada pokok bahasan luas bangun datar gabungan pada siswa kelas VI SD Negeri 02 Toyomarto Singosari meningkat dengan model pembelajaran kooperatif Jigsaw yang ditunjukkan dengan hasil posttest.

2. Model pembelajaran kooperatif Jigsaw dapat meningkatkan hasil belajar afektif siswa pada pelajaran matematika kelas VI SD Negeri 02 Toyomarto Singosari. Hal ini menunjukkan bahwa motivasi belajar siswa dipengaruhi oleh model pembelajaran yang diberikan guru. Motivasi belajar yang tinggi cenderung akan mempengaruhi prestasi belajar yang tinggi pula.

3. Model pembelajaran kooperatif Jigsaw membuat siswa lebih aktif, kreatif, penuh semangat, percaya diri, dan tidak cepat bosan dalam proses pembelajaran. 


\section{DAFTAR PUSTAKA}

Ali Imron; 1990, Teknik Belajar Yang Tepat, Semarang, Mutiara.

Arikunto, Suharsini; 1998, Prosedur Penelitian Suatu Pendekatan Praktek, Bandung, Tarsito.

Fadillah, Syaiful Alhadad; 2002, Model Pembelajaran Interaktif Dalam Pembelajaran Pertandingan Surabaya. Teori yang tidak dipublikasikan, Surabaya, Cerest.

Hobri. 2007, Penelitian Tindakan Kelas (PTK) untuk Guru dan Praktisi Jember; UPTD Balai Pengembangan Pendidik Dinas Pendidikan.

Hudoyo, Herman; 1988, Mengajar Belajar Matematika, Jakarta : P2LPTK (Proyek Pengembangan Lembaga Pendidikan Tenaga Kependidikan).

Lince, Rarak; 2001, Pengembangan Perangkat Pembelajaran dengan Pendekatan Struktural pada Pokok Bahasan Persamaan Garis di Kelas II SMP. Makalah Komprehenshif, Surabaya; Program Pasca Sarjana Universitas Negeri Surabaya.

Nasution S; 1988, Metode Penelitian Naturalistik Kualitatif, Bandung, Penerbit Tarsito.

Nurhadi \& Senduk, Agus Gerrod; 2003, Pembelajaran Instektual (Contextual Teaching and Learning/CTL) dan Penerapan dalam KBK, Malang UNM.

Nur, Muhammad; 2005, Pembelajaran Kooperatif Surabaya : Pusat Sains dan Matematika Sekolah UNESA.

Syaiful Sagala; 2006, Mari Memahami Konsep Matematika untuk Kelas VIII, Bandung : Grafindo Media Pratama. 
AL-ADZKA, Jurnal Ilmiah Pendidikan Guru Madrasah Ibtidaiyah

Volume VIII, Nomor 01, Hal (33-43)

Juni 2018 